\title{
CORALLINA FLABELLUM.
}

\section{우 \\ ChARACTER GENERICUS.}

Animal? crescens habitu plantæ.

Stirps fixa. Rami articulati, ramulosi.

CHARACTER SPECIFICUS, ङొc.

CORALLINA FLABELLUM. C. stipite simplici incrustato, \&c.

Lin. Syst. Nat. Gmel. p. 3842.

CORALLINA stipite simplici incrustato, ramis omnibus conglutinatis, fronde flabelliformi incrustata subundulata.

Soland. et Ellis Zooph. p. 124. t. 24.

Rupibus maris Americani adhærescit elegans hæc Corallinæ species; interdum major quam in tabula depicta. 


\section{MUSIBSATI AVIUTAROO}

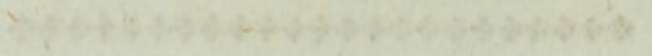

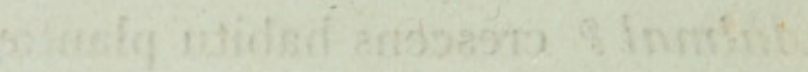

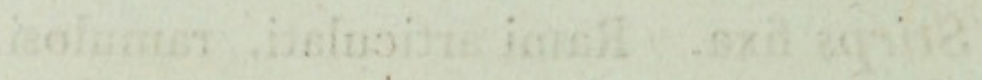

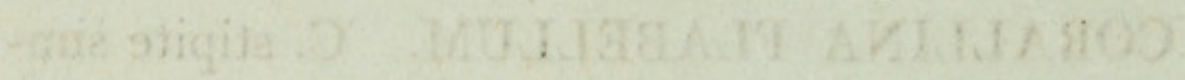

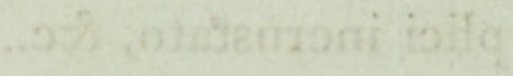

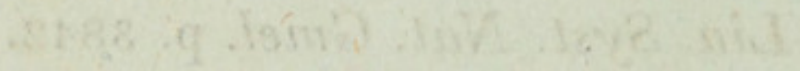

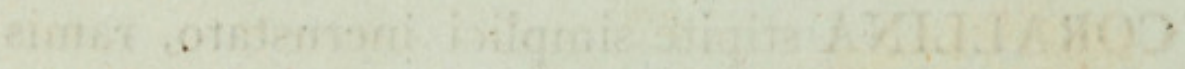

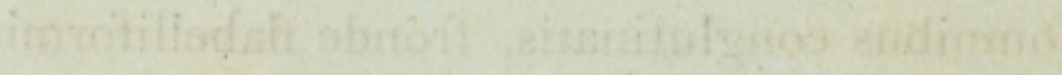

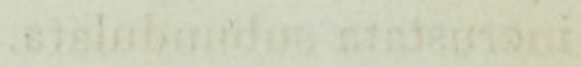

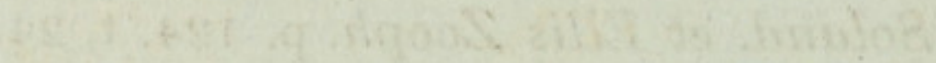





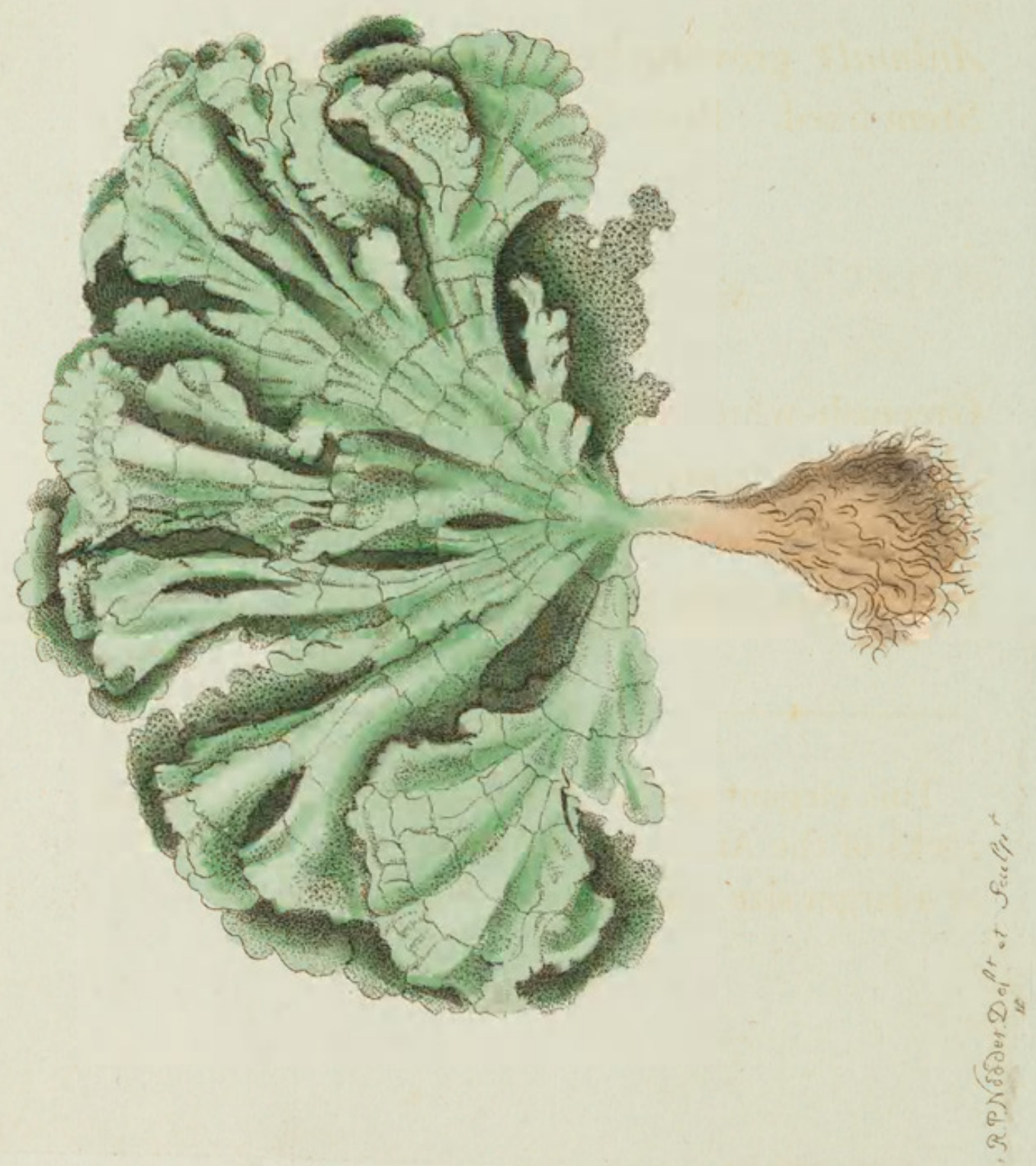


THE

\section{FAN CORALLINE.}

\section{$* * * * * * * * * * * * * * * * *$ \\ GENERIC CHARACTER.}

Animal? growing in the form of a plant. Stem fixed. Branches jointed and subdivided.

\section{SPECIFIC CHARACTER.}

Greenish-white CORALLINE, with simple stem, conglutinated branches, and fanshaped subundulated frond.

Fan-shaped CORALLINE.

This elegant species of Coralline is found on the rocks of the American seas, and sometimes arrives at a larger size than represented on the plate. 


\section{$2 \mathrm{BHL}$ Biodiversity Heritage Library}

Shaw, George. 1805. "The Fan Coralline, Corallina flabellum [PI. 658]." The Naturalist's Miscellany 16(CLXXXVII), https://doi.org/10.5962/p.311099.

View This Item Online: https://www.biodiversitylibrary.org/item/281942

DOI: https://doi.org/10.5962/p.311099

Permalink: https://www.biodiversitylibrary.org/partpdf/311099

\section{Holding Institution}

Museums Victoria

\section{Sponsored by}

Atlas of Living Australia

\section{Copyright \& Reuse}

Copyright Status: Public domain. The BHL considers that this work is no longer under copyright protection.

This document was created from content at the Biodiversity Heritage Library, the world's largest open access digital library for biodiversity literature and archives. Visit BHL at https://www.biodiversitylibrary.org. 